\title{
Volker Schlöndorff's Nameless Day: The Literary Adapter Goes Noir
}

\author{
Dr. George Lellis \\ Prof. Emeritus \\ Coker College \\ Dr. Hans-Bernhard Moeller \\ Prof. Emeritus \\ University of Texas \\ Austin, TX, Germanic Studies
}

\begin{abstract}
Nameless Day extends Volker Schlöndorff's film oeuvre of the literary adaption to a televisual version of Friedrich Ani's highly acclaimed eponymous crime novel. Not only the novel but also the made-for-television film differs from the usual detective story in that they explore the damaging effects of observing violence. Jakob Franck, the detective, in the movie becomes a character who is able to lead victims of violence to healing and closure. Schlöndorff overlays Ani's narrative with a visual approach that pays homage to the classic German films of the 1920s and to the Hollywood film noir. Although Schlöndorff makes changes in the time frame and location of the narrative, as well as the chronology and ending, he preserves those themes of the book that relate to silence and communication. Further, he creatively triangulates this dichotomy by adding components that demonstrate how visual expression can both confront and reduce alienation.
\end{abstract}

Keywords: television crime drama, healer detective, communication vs. silence

Few critics would associate Volker Schlöndorff, one of the leading representatives of the New German Cinema movement of 50 years ago, with the genre of the crime film. His previous, often moody studies of alienated men and women seem a far cry from the world of persistent police crime fighters and their law-breaking targets. The police procedural drama has long enjoyed a special niche in television programming, both in the U.S. and in Germany. It is not completely surprising, therefore, that the German filmmaker was attracted to the prospect of adapting Friedrich Ani's The Nameless Day (2015b, 2018b). Ani's novel had been hailed as not just a great crime story but also as a significant work of literature (Matzig, 2015; Krekeler, 2015). Although it is not Schlöndorff's first foray into crime narrative - A Degree of Murder (1967) and Palmetto (1998) have been largely overlooked — it is a project that melds logically with Schlöndorff's reputation as an adapter of fine literature.

If the usual crime film is about bringing the guilty to justice, Schlöndorff's Nameless Day is about relieving people who are either victims or onlookers of violent acts of the experienced guilt. It is less about the perpetration of violence than about the damaging effects of observing it. One could call it a post-action movie. Nameless Day is special because it creates a multi-faceted detective character as a man who is at once a messenger of death, an investigator, and a healer. It extends and varies the film noir tradition. Despite Schlöndorff's marked changes to the novel, the film maintains the original motifs of silenced communication and observed suffering. Schlöndorff overlays Ani's story with a visual discourse about how words and imagery can create human contact.

\section{Messenger, Observer, Healer}

2.1 Schlöndorff has stated that what attracted him to Friedrich Ani's novel The Nameless Day was that he saw Ani as an observer of human behavior rather than as an inventor of contrived fictional situations ("Zusammenarbeit," 2018d). Ani had apparently based the character Jakob Franck on a real-life female police officer whose regular job was informing people that a loved one was dead ("Fragen an Romanautor," 2018). In addition, part of the story had its roots in a true account of a female police inspector who actually did comfort a deceased victim's loved one with an embrace that lasted several hours (Ani, 2015a,"Jeder ist allein," and 2015b, "Die Psychologie"). A switch of genders creates an engaging contrast between a police inspector, a traditionally hyper-masculine role in crime fiction, and the nurturing and comforting qualities required of a humane bearer of tragic tidings. 
2.2 We first see the character of Jakob Franck as he knocks on doors to report on the demise of a beloved. We see a bride-to-be confront the news of the death of her fiancé with hysteria. A vivacious woman of African descent likewise collapses in tears. In the detective's third visit we see an elderly man playing chess in a café stoically continue the game and also offer the inspector a beer - after he hears that a car has fatally struck his wife. This trio of examples sets up the traditional stereotypes of emotional women and affectless men that the movie will explore.

2.3 Only later do we learn that Franck is voluntarily performing these duties after his retirement. He seems driven to continue these emotion-laden encounters as a matter of choice. Nameless Day's narrative begins when Franck receives a call from Ludwig Winther, the father of a teenage girl whose death by hanging two years ago had been ruled a suicide. Winther's wife, Doris, has just hung herself on the anniversary of their daughter Esther's death. Ludwig is convinced that the death of the daughter was not a suicide and asks Franck's help to find the murderer.

2.4 In the process, Franck takes on two additional roles: he becomes not just a messenger of death but also an observer-investigator and eventually a healer. Only the observer-investigator role is traditional for the crimemovie genre. Nameless Day unfolds by revealing layers of observation even by characters other than the police inspector. Ludwig at times seems like a stalker, snooping on Franck, the investigator. Similarly, Patrick Jordan, a young boy in the neighborhood, is portrayed watching and eavesdropping on the detective. In a wider sense, Ludwig has seen the hard-to-explain disintegration of his family. Doris's sister, Inge Nemetzki, has similarly seen from afar the loss of her niece and her sister. And Patrick, whose major scenes occur late in the film, has witnessed, directly but passively, the death of his mother at the hands of his father. Throughout Nameless Day characters watch other characters suffer and the film audience in turn is pulled into this vortex of observation.

\section{In the Film Noir Tradition}

3.1 The movie opens with disturbing shots of Esther's body hanging from a tree in the park. Schlöndorff uses an updated version of the Billie Holiday anti-lynching classic "Strange Fruit" on the sound track. As the investigative story develops, narrative tension emerges not from the threat of characters being put into danger, but from the anxiety that comes from knowing that future revelations may uncover something even worse. It is gradually revealed that the teenage Esther may have had an affair with a neighboring dentist, Dr. Jordan, Patrick's uncle and foster father, and later the possibility emerges that Ludwig may have molested his own daughter. With the weight of potential guilt hanging over several characters, Nameless Day begins to seem closer to Greek tragedy than to crime melodrama.

3.2 If one wants to classify Nameless Day as a genre film, it has certain affinities with the film noir. There is a characteristic sense of the moral ambiguity associated with film noir and Franck occupies a kind of middle ground between being part of the law and a private investigator. His returning home as a single divorced man to a dreary, dimly lit home is a familiar trope of the noir genre. Schlöndorff has stated that he and his cinematographer, Tomas Erhart, were striving for the look of the classic German silent film ("Fragen an . . Schlöndorff," 2018b). Such a style was, of course, the source for the full-blown noir imagery at its height.

3.3 Although shot in color, Erhart's cinematography uses high-contrast lighting, pools of shadow, back-lit images, and striking compositions - some scrupulously balanced, some off-center - again following in the tradition of early German cinema and the noir genre. In his early scenes in the film, the Ludwig Winther character is shown with back lighting, making him appear as a black contour with shadows.

The house that the Winthers live in is particularly reminiscent of some of the sets one sees in the movies of Fritz Lang. Grids of tile, glass bricks or flooring, and geometric windows create busy patterns that surround conflicted characters and echo their confusion. Nameless Day uses a highly restricted color palette that produces much of the effect of black-and-white photography. There are almost no reds, yellows or purples, except in flashbacks and a few key shots, and the greens and blues that appear are muted and subdued. Browns, grays, whites and blacks predominate. The action takes place in dull, wintry landscapes, sometimes in the rain and often in banal urban and suburban settings. The few shots of Erfurt cathedral or the pretty countryside only serve to heighten the dullness of the environment.

3.4 In keeping with the noir tradition, Franck seems at first a hero who does few heroics. He plods through the investigation with an emotional passivity. For much of the movie, he appears as a kind of neutral cipher whose sole purpose is to get others to talk and react. As a quiet father figure, he seems both threatening and reassuring. The story frequently contrasts acts of talking with acts of silence. 
A flashback to a scene in which Franck breaks the news of Esther's death to the girl's mother portrays his extended silent embracing of the mother as the surroundings move from daylight to night. The scene subtly conveys Franck's main motivation for becoming again involved in the case. The one situation where Franck reveals his inner feelings is when he talks to his ex-wife at her bookstore.

\section{A Cinematic Adaptation for Television}

4.1 Turning from genre to media-related concerns, we find that Nameless Day was always conceived as a vehicle for television. Rather than relying on simplistic TV style close-ups, it, however, frequently has the visual and aural complexity of a good theatrical film noir. In light of these characteristics, it was included in the official selection of the Filmfest Hamburg and actually made its debut there on Oct. 9, 2017, well before its broadcast by German pubcaster ZDF on February 5, 2018 (Filmfest, 2017). The director has done some remarkably good work for the small screen, especially with pieces like Baal and Georgina's Reasons in the 1970s. His first forays into American filmmaking were both through television, with the adaptation for CBS of the Dustin Hoffmann stage production of Death of a Salesman in 1985 and the subsequent adaptation of Ernest Gainses's A Gathering of Old Men (1987), both of which received theatrical release in Europe. He has spoken about the benefits of working for television, in particular the lack of worries about financing and marketing ("Tatort," 2018). One can imagine how Nameless Day might have been undermined had it been saddled with a big budget, star performers, and an economic need for wide-spread box office success. In contrast to the star glamor associated with the theatrical feature, its characters have an ordinary, everyday look to them. The women, even the attractive ones, are not glamorized with noticeable make-up, and little imperfections in the performers' skin are allowed to remain. In its current form, the work impresses with the amount of visual invention it achieves with the modest budget.

4.2 In adapting Friedrich Ani's crime novel to the screen, the filmmaker made several significant changes. Few of these changes detract from the virtues of the source material; most have to do with practicalities of film production and the streamlining of the novelistic narrative. The changes involve relocating the setting from Munich to Erfurt, shortening the time frame between Esther's hanging and Franck's investigation from twenty years to two years, making Doris and Inge twin sisters who could then be played by the same actress, and fully introducing Patrick near the end of the story rather than at its very beginning.

4.3 The geographic change was due in part to how the lead actor, Thomas Thieme, was uncomfortable with assuming the Bavarian accent required for the Munich setting (Schlöndorff, 2018d, "Zusammenarbeit"). Erfurt was close to where the actor had grown up and Schlöndorff liked the idea of setting the story in a small city that unlike Munich would not be chic. Rather, it would be a place that young people would be eager to leave (Schlöndorff, 2018a, "Audiodatei").

4.4 The change in time frame grew in part out of Schlöndorff's desire to avoid either to have to age the actors or to cast different performers for the different time periods. The book, unlike the film, also portrays Ludwig as going into a personal and professional decline, losing his job, car, and house.

4.5 The choice to make Doris and Inge twins grew in part out of Schlöndorff's desire to give the actress Ursina Lardi a more challenging role. This results in making the characters two sides, as it were, of a single coin. Inge, an artist who is teaching art in Berlin, contrasts to Doris who has given up artistic and academic ambitions to assume a more conventional role of wife and mother. These two paths seem to embody the choices facing Esther when she graduates from high school. Esther seems to favor the more bohemian life-style of her aunt who chain-smokes and drinks excessively. Esther's ambivalence about roles is evidenced in her sometimes wearing a black "gothpunk" wig, while at other times allowing her natural blond hair to fall around her shoulders.

4.6 When Schlöndorff places Patrick's major part at the end of the story, apart from a passing entrance inappropriately on a skateboard, following Esther's funeral, this probably has to do with the changing of the time frame. Patrick is the key to the solving of the mystery. Ani begins the novel with Patrick viewing his mother's murder and that trauma becomes a way to create a more developed character, one with a deviant streak, who has experienced a second trauma, Esther's death. This further develops Ani's motifs of characters witnessing the pain of others. The novel, in effect, begins with a Freudian primal scene in which the child's fear that the father is hurting the mother is made real. As presented very quickly but later in the film Nameless Day, the moment forms a reverberating parallel to the scene in The Tin Drum, in which the young Oscar, hiding in the cupboard, witnesses his mother and lover/cousin Jan Bronski at foreplay. In the recent movie, the child's bearing witness to the accident of Esther's inadvertent hanging becomes a little more of a contrivance used to resolve the story rather than a central image that resonates against the similar images that follow. 


\section{Modernist Structure, Humanist Theme}

5.1 Schlöndorff retains two strategies from the novel, the modernistic, fragmenting structure and the theme of lack of communication. His Nameless Day jumps back and forth between Franck's investigation and the events before and after the two hangings. The effect is purposefully disorienting and the quick flashbacks are often stylistically different from the rest of the movie. They repeatedly use brighter and warmer colors, freer camera movements, alternating shifts in apparent shutter speed, and mild distortions of the sound track. A particularly striking example is in the scene where Franck is interviewing the lady who discovered Esther's body. They are near the tree where the death took place and the filmmaker cuts between shots of the woman walking her dog with the body hanging in front of her and shots of her walking the same dog with Franck next to her and empty branches. The effect of these time shifts is unnerving. Other flashbacks show Esther's visits to her aunt, her free partying with friends, and moments of familial happiness. Past and present mingle, Erfurt is contrasted with Berlin, and energetic cheer is juxtaposed with grieving.

5.2 Although Schlöndorff changes the structure of the novel, he does so in a film-specific way that has a similar effect. And he successfully keeps from the literary model the emphasis on the negative effect that can result from a cold lack of communication between husband and wife and between parent and child. Almost every scene of the film plays on the contrast between silence and communication. Death has the effect of silencing both the person no longer living and those left behind. The long silent embrace between Doris and Franck is a clear example of this, but there is also the apparent effect of a drying up of communication between Doris and Ludwig, and earlier between Doris and her sister Inge.

5.3 The characters of Esther's boyfriend Jan Roland and her best girlfriend Sandra Horn underline an intergenerational divide. Together these youths dream of something more than, and different from, the lives of their parents. When Franck interviews each of them, they both display a sullenness and distrust that may arise from Franck's status as an authority figure. Jan's great wariness of Franck is evident when the detective invites him for a talk in a café. Sandra exhibits a comparable distrust of Dr. Jordan when the two run into each other at a disco and the dentist asks where Esther is. Sandra lies, telling him she is not around anywhere. Repeatedly, Ludwig goes to his daughter's room and wants to talk to her, but she turns him away, saying that there's nothing to talk about.

5.4 Franck himself seems a quiet, silent figure, once he has delivered his bad news. Yet it is through getting others to talk that he is able to get at the truth. As he tries to get to the bottom of the rumors and presumptions about Esther and Dr. Jordan or possible incest between father and daughter, he can progress only to the extent that people talk. At one point Ludwig asks Franck to stop his inquest, and even offers him money "for expenses" if he will halt his search. On the one hand, this attempted payoff, evocatively staged in the cold rain, leads the audience to suspect guilt on Ludwig's part, but we see in retrospect that it arises out of Ludwig's fear of knowing the truth.

5.5 Once the truth comes out, we see Ludwig as the man seriously harmed by both the absence of communication and the two women most important to him. His daughter has used the rumors of incest as a way to free herself from controlling parents. His wife, rather than confront him about the rumors, has chosen to believe them. Although both acts signal a lack of trust and love, he has been complicit in the silence that the three have maintained. In a series of scenes near the end of the film, Franck begins to metaphorically expose Ludwig's wounds and allow them to heal. When the two men enter Ludwig's home, a shot of the two of them coming through the door is aimed at some bright red tomatoes sliced on a table in the foreground, a passing still-life within the composition. This is the brightest red seen so far in the present-day scenes of the film. A few minutes later, Franck notices a scar on Ludwig's hand and there is a quick flashback to a scene in which the father protects his daughter from an angry dog, taking the dog bite himself. The moment proves the father's love for his daughter and also may be the most brightly colored scene with reds, oranges, and yellows.

5.6 The film's mood established by the integration of this flashback episode prepares for Franck's moment of therapeutically liberating Ludwig from his guilt feelings and repressed speech and sets up the resolution of the story. The inspector, as in a ritual, urges the inhibited father-victim to pronounce after him: "I, Ludwig, let you go, Doris." ii Breaking his persistent silence only with great difficulty, Ludwig, after several attempts manages to repeat the detective's charm phrase, only to be subsequently urged on to pronounce the same about his daughter Esther. Franck assumes the role of healer. This is in contrast to Ludwig's phone calls to Franck at the film's outset. 
In the very first call, he hangs up without talking. In the second, he speaks only with great hesitation and difficulty. Toward the conclusion of the film, we see him with hands outstretched and pressed to the pane of the window looking out at the garden where Doris hanged herself. He is now prepared to speak on his own the ritual formula about letting Doris go, and repeats it, by himself, a second time in the plural form applying to both his wife and his daughter, "I let you go." In the literary model, Ani employs this verbal magic earlier in the narrative than Schlöndorff. The director makes this scene the climax of the film, whereas Ani's much more downbeat ending presents Ludwig sinking back into depression. Franck can only attempt being Ludwig's healer in the novel.

\section{A Discourse about Images}

6.1 Yet the movie does not just construct a simple opposition between alienating silence and liberating verbalization. Instead, it triangulates its schema by creating a role for images in the understanding of truth. This role of images is first manifest in the scene where Ludwig initially enters Franck's home. He sees a small picture on the wall, a landscape with a tree that eerily resembles the tree of Esther's hanging. Ludwig is slightly taken aback, as is the audience. It is as if the tree inspires Ludwig to talk and open up a bit. In a quick flashback we see Esther walking toward her death tree and hear a voice, presumably Patrick's, on the sound track calling her name.

6.2 The narrative similarly suggests that Inge, as an artist, uses images to process her reality. As Inge waits for Franck in a bar, she draws a sketch of a body hanging with a noose from a tree. As the scene develops we see two other drawings, one with two bodies hanging, the other of Doris and the inspector locked in their extended embrace. The scene reaches a dramatic climax when, after Franck asks Inge to draw him a picture of her sister, she unexpectedly slams his head with her pocketbook. Images, like words, can be scary. One may sometimes want to repress them as when Inge quickly erases a drawing she has done on a blackboard in chalk as soon as she sees Franck take out his phone to take a picture of it.

6.3 At the conclusion of the film, Franck's ex-wife gives him a large mailing-envelope that has been delivered for him at her bookstore. It turns out to be a portrait of either Doris or Inge; we cannot tell whose image it is. Inge has sent him a portrait of either herself or her sister. She has either fulfilled his request for the latter or indicated some feelings for him with her self-portrait. The gesture reflects Franck's apparent feelings for both women as they have affected him over the course of the narrative.

6.4 Nameless Day's major discourse on images, however, occurs in two scenes in which Franck reclines at home staring at the shadows on the ceiling. He sees flashing, moving images related to the work he is doing, although some images from the flashback are things he could not have experienced directly. In the first scene, we learn through Franck's voice-over that he regularly uses these projected mental images as a way to solve cases on an instinctive, intuitive level. These expressionistic, evocative montages are striking in both their simplicity and their emotional resonance. On the one hand, the visual device is almost primitive, reminding one of the special effects in short films by George Méliès. Similar effects have occurred in the movies of Fritz Lang, such as Liliom. On the other hand, there is something haunting about this graphic equation of subconscious projection and fantasy with the movie-going experience. This self-reflexive trope, inscribing the viewer's experience into the film itself, is present also in Ani's novel, unlike the previously mentioned drawings that Schlöndorff has added to the story. Ani writes: "One morning Franck decided not to go to work; he closed the door to his study, pulled the blue woolen blanket off the couch, spread it out across the parquet, lay down, stretched out his arms and legs and began to project his thoughts onto the white of the ceiling, while paying attention to what he found in each piece of the puzzle, like he was watching a film for the first time, curious to see whether what was happening would change him from being a distant viewer into a reflective human being" (2018b, 151). Schlöndorff renders concrete Ani's description of the parallels between cinema and the subconscious.

6.5 As in his previous filmReturn to Montauk, the screenwriter/director Schlöndorff employs the film medium to reflect on the creative process. Indeed, these last two efforts by Schlöndorff both center around male figures late in their careers — like the filmmaker himself — who are reflecting on past events and trying to right past mistakes. In the case of Nameless Day it would be the earlier police investigation that failed to find the truth. It may be mere coincidence that Erfurt is the hometown of Schlöndorff's mother but one may also recall that the director experienced the truly traumatic event of his mother perishing in a fire and his being unable to get to her to help (Schlöndorff, 2008, Licht,p. 16). Although it is hardly autobiographical in the way Return to Montauk is, the film is not without such personal nuances. 
The characters in Nameless Day configure into striking pairings and parallels. Franck shares with Ludwig the experience of being alone after an ended marriage. Patrick shares with Ludwig the pain of watching two women close to him both die. Esther and her closest girlfriend Sandra have, like the two sisters Inge and Doris, experienced both closeness and alienation resulting in silence. Esther and her aunt crave an artistic life away from the small city. The spectator, like Franck, tries to make sense of and give coherence to flashing images that at first glance appear random and disorganized.

\section{Reception}

The Nielsen-type ratings document that 5.85 million viewers viewed Nameless Day when the second German pubcaster ZDF broadcast it on February 5, 2018, which corresponds to a market share of 18\% for ZDF (Weis, 2018). Critical response, while overwhelmingly positive, tended to fall into two categories. Some critics praised the work for expanding the television crime genre beyond mere entertainment. Rainer Tittelbach (2018) of the fernsehfilm-beobachter, calling the work "a little masterpiece" writes that it "conveys everything that could make the film to a crime movie, in truth, however, it is more than that, in any case it tells very much more than this genre's numerous TV offshoots." In the Hamburger Abendblatt, Frank Preuß (2018) commented that "Perhaps it needs precisely a film narrator with a fresh [unverstellten] look, who is able to offer us who are supersaturated with crime films an investigator whom we follow so spellbound as this Jacob Franck in Nameless Day." This reviewer also qualifies the film as a "masterpiece." Others, however, complained of an unvarying downbeat tone and dramatic sluggishness. According to Christoph Schröder (2018) of Die Zeit "the film persists in its heavy thoughtfulness . . . without driving the action forward." Reviewer Hans Hoff (2018) of the Süddeutsche Zeitung may reflect the two sides of reviews, writing: "Schlöndorff fans will love that: this slow tempo, this play with the dither and dream images, these inquiring faces. Persons of the generation Netflix, however, may have their problems with the deliberate tone and many an intricacy and wish that something would happen."

\section{Conclusion}

Nameless Day enriches the genre of the crime film by expanding its thematic geography beyond the mapping of the territory of crime and the workings of justice. Author Ani had created a humanized and humanizing detective who strives to heal both others and himself. Schlöndorff realizes this character in movie-specific terms, combining the worlds of verbal logic and imagistic intuition.

\section{References}

Ani, F. (2015a, Nov. 5 and Nov. 19). Jeder ist allein. Interview mit Tobias Gohlis. Die Zeit Number 45. Available: https://www.zeit.de > DIE ZEIT Archiv > Jahrgang 2015 > Ausgabe: 45.

---. (2015b). Der namenlose Tag. Berlin: Suhrkamp Vlg.

---. (2015c, Nov.27), Die Psychologie hinter der Wahrheit. Interview mit Sandra Hoffmann. Deutschlandradio. Deutschlandfunk. Available: https://www.deutschlandfunk.de/friedrich-ani-der-namenlose-tag-diepsychologie-hinter...

---. (2018a, Feb.5). Fragen an Romanautor Friedrich Ani. Interview mit Birgit-Nicole Krebs und Mirja Bauer. ZDF Presseportal. Available: https://presseportal.zdf.de/pm/der-namenlose-tag/.

---. (2018b).The Nameless Day. Trans. Alexander Booth. London: Seagull Books.

Filmfest Hamburg. Programmheft. (2017). Retrieved from https://www.filmfesthamburg.de/download/bildmaterial/2017/Filmfest_Hamburg_Programmheft_2017v2 .pdf.

Hoff, H. (2018, Feb. 4). Fernsehen auf Schlöndorff-Art. Süddeutsche Zeitung. Retrieved from www.sueddeutsche.de/medien/zdf-montagskrimi-fernsehen-auf-schloendorff-art-.1.3853659.

Krekeler, E. (2015, Aug.1) Rezensionsnotiz zu Der namenlose Tag. Die Welt. Retrieved from https://www.perlentaucher.de/buch/ friedrich-ani/der-namenlose-tag.html.

Matzig, G. (2015, Aug. 7). Vom Ausgraben der Wahrheit. Süddeutsche Zeitung. Retrieved from http://www.sueddeutsche.de/kultur/kriminalliteratur-vom-ausgraben-der-wahrheit1.2599200?reduced=true. Also available:https://www.buecher.de/shop/muenchen/der-namenlose-tagjakob-franck-bd-1/ani-friedrich/products_products/detail/prod_id/42777539/. 
Preuß, F. (2018, Feb. 5). Volker Schlöndorffs erster Krimi ist ein Meisterstück. Hamburger Abendblatt. Retrieved from www.abendblatt.de/kultur-live/tv-und-medien/article213332877/Volker-Schloendorffs-erster-Krimiist-ein-Meisterstueck.html.

Schlöndorff, V. (2018a.) Audiodatei mit O-Tönen von Volker Schlöndorff, 2018, ZDF Presseportal. Pressemappe. Available: https://presseportal.zdf.de/pm/der-namenlose-tag/.

---. (2018b, Feb. 5). "Fragen an Drehbuch-Autor und Regisseur Volker Schlöndorff." ZDF Presseportal. Pressemappe. Available: https://presseportal.zdf.de/pm/der-namenlose-tag/. Also on line https:www.zdf.de/filme/der-fernsehfilm-der-woche/videos/videos/interview-schloendorff-tag-e100.html\#autoplay=true.

---. (2008). Licht, Schatten und Bewegung. München: Hanser Vlg.

---. (2018c) Tatort reizt mich bis heute nicht. Interview with Rudolf Ogiermann.Available:https://www.merkur.de/tv/interview-mit-regisseur-volker-schloendorff-ueberseinen-zdf-krimi-namenloser-tag-9586604.html.

---. (2018d, Feb. 2) Die Zusammenarbeit von Volker Schlöndorff und Friedrich Ani für Der namenlose Tag. Interview. ZDF. Available: (until May 3, 2018. https:www.zdf.de/filme/der-fernsehfilm-derwoche/videos/videos/interview-schloendorff-tag-e-100.html\#autoplay=true.

Schröder, C. (2018, Feb. 5) Der namenlose Tag: Ein Mann für all die Toten. Die Zeit.Retrieved from http://www.zeit.de/kultur/film/2018-02/der/namenlose-tag-volker-schloendorff-kritik.

Tittelbach, R. (2018, Jan. 12). Thieme, Striesow . . Ani, Verführung zur Wahrheit(ssuche). fersehfilm-beobachter. Available: www.tittelbach.tv/programm/fernsehfilm/artikel-4873.html.

Weis, M. (2018, Feb. 6). Primetime-check: Monday, Feb. 5, 2018.Quotenmeter. Available:www.quotenmeter.de/n/98871/.

Notes

${ }^{\mathrm{i}}$ The authors are indebted to Provobis, Gesellschaft für Film und Fernsehen, Germany, for providing access to a DVD of Der namenlose Tag, thereby allowing closer study of the film.

ii Translations from German are the authors' own. 